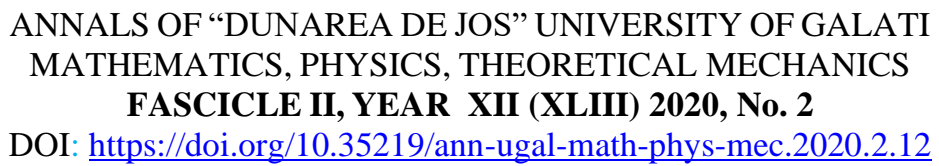

\title{
Atmospheric space observations over the world heritage sites in danger
}

\author{
Daniel-Eduard Constantin ${ }^{1, *}$, Adrian Rosu ${ }^{1}$, Mihaela Timofti ${ }^{1}$ \\ 1 "Dunarea de Jos" University of Galati, Faculty of Sciences and Environment, INPOLDE research center, \\ 800008 Galati, Romania \\ *Corresponding author: Daniel.Constantin@ugal.ro
}

\begin{abstract}
In this paper, we present an estimate of the level of air pollution and radiation flux over the most important world heritage sites which are in danger according to the United Nations Educational, Scientific and Cultural Organization (UNESCO). According to UNESCO, there are 36 sites that are in danger. The influence of air pollution and radiation on these sites are presented in this work. To achieve the objective we used information about black carbon and shortwave radiation using models and remote sensing instruments from space. We found that the cultural heritage from Europe is more exposed to black carbon while the cultural heritage is exposed to a high level of a shortwave radiation flux.
\end{abstract}

Keywords: air pollution, atmospheric models, world heritage sites, degradation

\section{INTRODUCTION}

The cultural heritage is a very important element of our individual and collective identity. The destruction of the cultural heritage may have negative implications on human development. The main objective of this paper is to determine an estimate of the radiation and air pollution level over the most important world heritage sites which are in danger according to the United Nations Educational, Scientific and Cultural Organization (UNESCO) list [1]. The UNESCO world cultural heritage contains 869 sites distributed over 148 countries. According to UNESCO, 36 sites are in danger. This list of sites in danger was performed after a two-year of consultations with experts in natural and cultural heritage. The list was created based on 14 primary factors most of them comprising also a number of secondary factors. The experts found that the most important factors are: buildings and development, transportation infrastructure, utilities or service infrastructure, biological resource use/modification, etc, and pollution. In this work, the pollution factor will be presented from the perspective of air pollution. It is well known that atmospheric pollution is an important element which led to the degradation of the historical monuments, surfaces of buildings, etc. According to experts, the impact of pollutants emitted into the atmosphere on materials is very high and sometimes irreversible. Also, air pollution can lead to chemical corrosion and particle dirt which may destroy the cultural heritage. Figure 1 presents the location of the world's cultural heritage, including the sites in danger. A similar study was performed over Romania in 2019 [2]. 


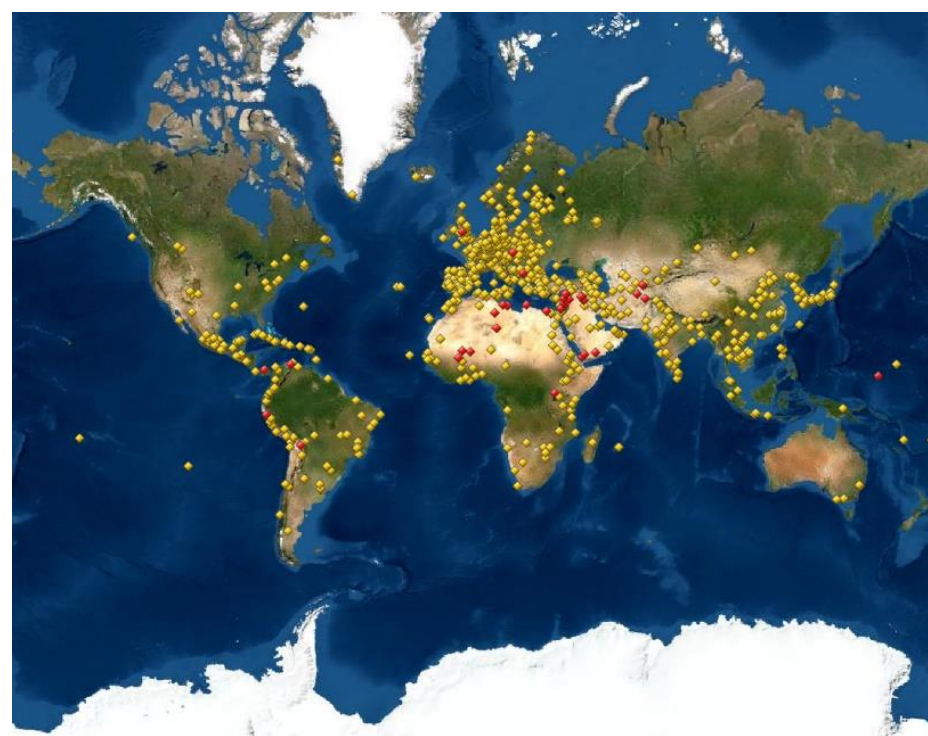

Fig. 1. The world heritage sites including the sites in danger (red colored), (Source: https://whc.unesco.org/en/danger/)

\section{EXPERIMENTAL}

The UNESCO world cultural heritage contains 869 sites distributed over 148 countries. According to UNESCO, 36 sites are in danger [1]. The distribution over the continents of the world cultural heritage in danger: Latin America and the Caribbean: 4; Europe and North America: 3; Asia and the Pacific: 4; Arab States: 21; Africa: 4. Figure 2 presents the $\mathrm{NO}_{2}$ distribution over the world using TROPOspheric Monitoring Instrument (TROPOMI) observations [3]. It can be observed that the most polluted places are: North America, East Asia, and Europe. Table 2 presents the distribution of the UNESCO heritage in danger at the national level. There are several countries that contain more than three cultural heritage in danger: Libya, the Syrian Arabic Republic, and Iraq. For this study, we selected 10 countries: Afganistan, Austria, Bolivia, Egypt, Iraq, Libya, Mali, Syria, UK, Venezuela. To achieve the purpose of this work we show the annual average of the Black Carbon and Shortwave Flux over the selected countries. It is well known that black carbon and shortwave radiation have a negative influence on the cultural heritage $[4,5]$.

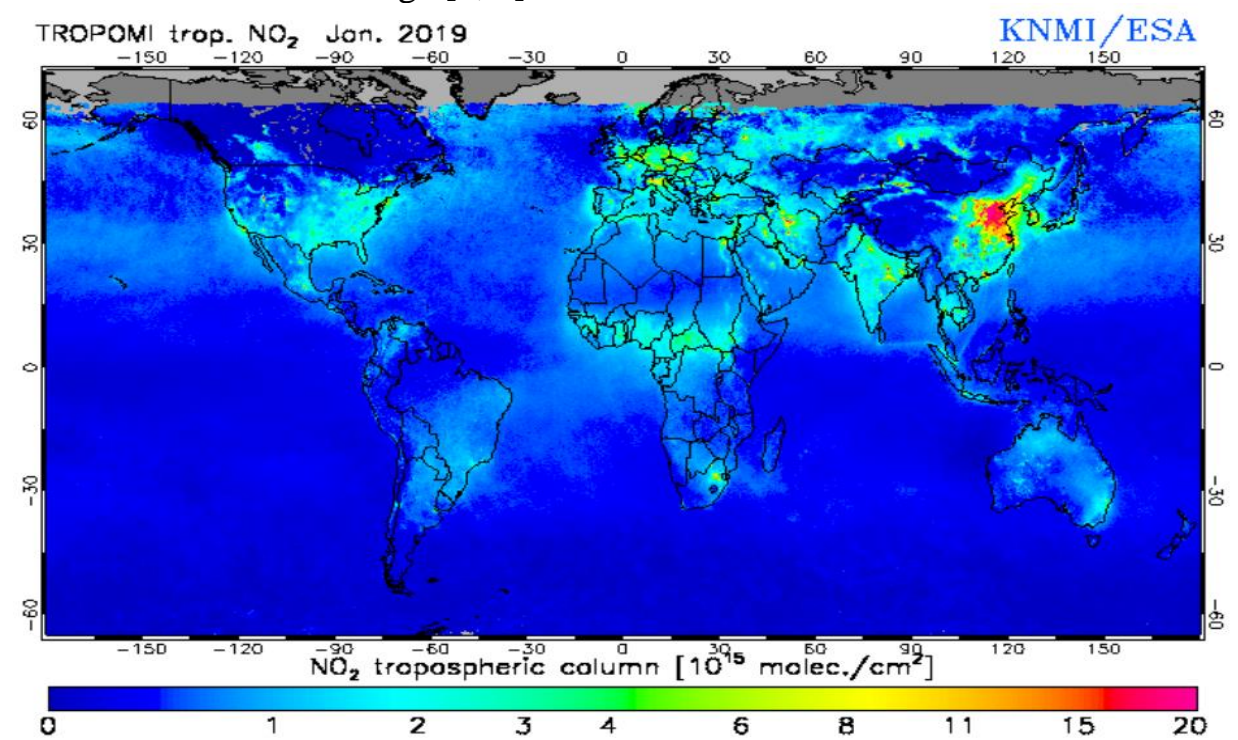

Fig. 2. The $\mathrm{NO}_{2}$ distribution over the world using TROPOMI observations (www.temis.nl) 
Table 1. The UNESCO cultural heritage in danger and their countries (Source: https://whc.unesco.org/en/danger/)

\begin{tabular}{|c|c|c|}
\hline $\begin{array}{l}\quad \text { Afghanistan } \\
\text { Minaret and Archaeological } \\
\text { Remains of Jam } \\
\text { Cultural Landscape and } \\
\text { Archaeological Remains of } \\
\text { the Bamiyan Valley }\end{array}$ & $\begin{array}{l}\text { Austria } \\
\text { Historic Centre of Vienna } \\
\text { Bolivia } \\
\text { City of Potosí }\end{array}$ & Abu Mena \\
\hline $\begin{array}{l}\quad \text { Iraq } \\
\text { Hatra } \\
\text { Ashur (Qal'at Sherqat) } \\
\text { Samarra Archaeological City }\end{array}$ & $\begin{array}{l}\text { Jerusalem (Site proposed by } \\
\text { Jordan) } \\
\text { Old City of Jerusalem and its } \\
\text { Walls }\end{array}$ & \begin{tabular}{l}
\multicolumn{1}{c}{ Libya } \\
Archaeological Site of \\
Cyrene \\
Archaeological Site of Leptis \\
Magna \\
Archaeological Site of \\
Sabratha \\
Rock-Art Sites of Tadrart \\
Acacus \\
Old Town of Ghadamès
\end{tabular} \\
\hline \begin{tabular}{l}
\multicolumn{1}{c}{ Mali } \\
Old Towns of Djenné \\
Timbuktu \\
Tomb of Askia
\end{tabular} & $\begin{array}{l}\text { Micronesia } \\
\text { Nan Madol: Ceremonial } \\
\text { Centre of Eastern Micronesia }\end{array}$ & $\begin{array}{l}\text { Palestine } \\
\text { Palestine: Land of Olives and } \\
\text { Vines - Cultural Landscape } \\
\text { of Southern Jerusalem, Battir } \\
\text { Hebron/Al-Khalil Old Town }\end{array}$ \\
\hline \begin{tabular}{l}
\multicolumn{1}{c}{ Panama } \\
Fortifications on the \\
Caribbean Side of Panama: \\
Portobelo-San Lorenzo
\end{tabular} & $\begin{array}{l}\text { Peru } \\
\text { Chan Chan Archaeological } \\
\text { Zone }\end{array}$ & \begin{tabular}{l}
\multicolumn{1}{c}{ Serbia } \\
Medieval Monuments in \\
Kosovo
\end{tabular} \\
\hline $\begin{array}{l}\quad \text { Syrian Arab Republic } \\
\text { Ancient City of Damascus } \\
\text { Ancient City of Bosra } \\
\text { Site of Palmyra } \\
\text { Ancient City of Aleppo } \\
\text { Crac des Chevaliers and } \\
\text { Qal'at Salah El-Din } \\
\text { Ancient Villages of Northern } \\
\text { Syria }\end{array}$ & \begin{tabular}{l}
\multicolumn{1}{c}{ Uganda } \\
Tombs of Buganda Kings at \\
Kasubi
\end{tabular} & $\begin{array}{c}\text { United Kingdom of Great } \\
\text { Britain and Northern Ireland } \\
\text { Liverpool - Maritime } \\
\text { Mercantile City }\end{array}$ \\
\hline $\begin{array}{l}\quad \text { Uzbekistan } \\
\text { Historic Centre of } \\
\text { Shakhrisyabz }\end{array}$ & $\begin{array}{l}\text { Venezuela } \\
\text { Coro and its Port }\end{array}$ & \begin{tabular}{l}
\multicolumn{1}{c}{ Yemen } \\
Old Walled City of Shibam \\
Old City of Sana'a \\
Historic Town of Zabid
\end{tabular} \\
\hline
\end{tabular}

\section{RESULTS AND DISCUSSION}

Figures 1 and 2 present the monthly average Black Carbon Surface Mass Concentration respectively the average surface incoming shortwave flux (clear sky) over the selected countries using 0.5 x 0.625 pixel degree. The Average Black Carbon Surface Mass Concentration and the average Surface Incoming Shortwave Flux are obtained from the „Modern-Era Retrospective analysis for Research and Applications version 2, (MERRA-2), which is a NASA reanalysis atmospheric model for satellite based on „Goddard Earth Observing System Model, Version 5” (GEOS-5) [6]. 
Figure 3 shows that Austria is the country with the highest Black Carbon content while Libya is the country with the lowest Black Carbon content.

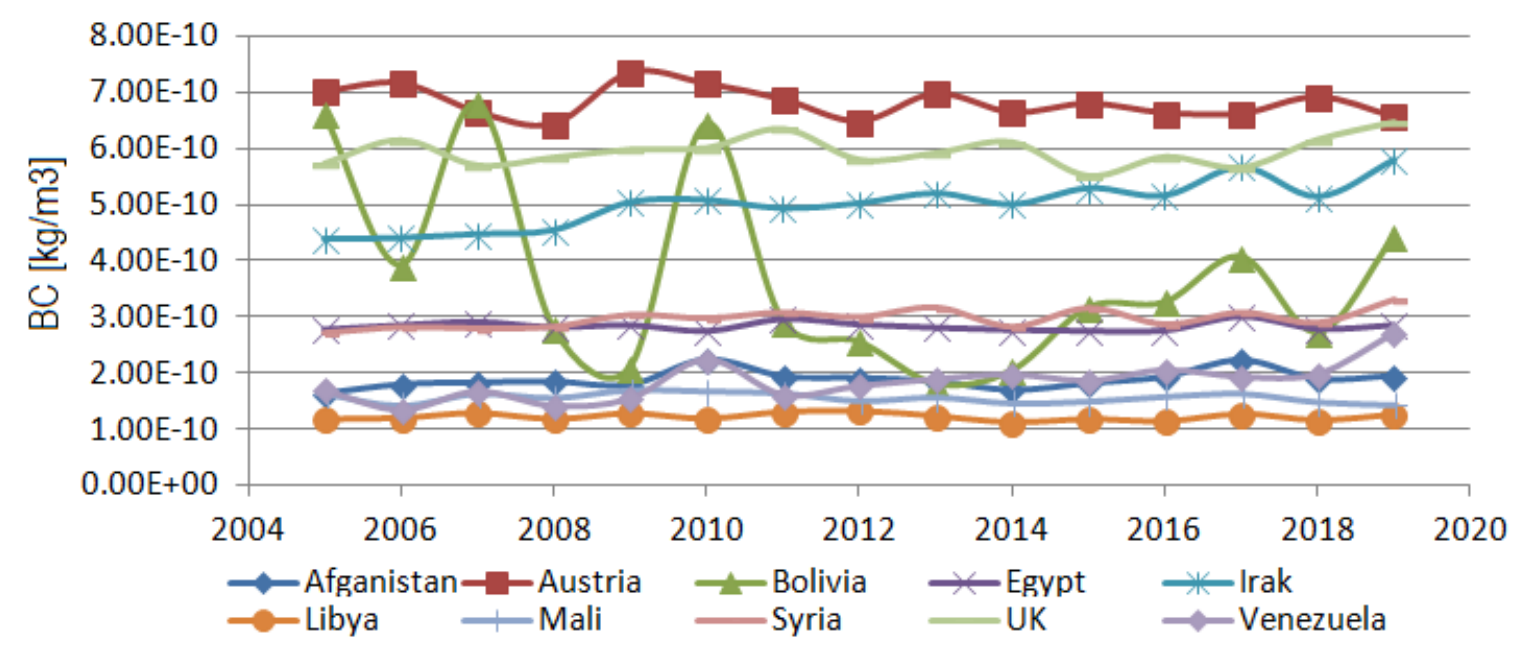

Fig. 3 The average Black Carbon surface mass concentration over the selected countries

Figure 4 shows the level of the surface incoming shortwave flux over the selected country during 1980-2019. Figure 2 shows that Venezuela and Bolivia are the countries with the highest level of surface incoming shortwave flux radiation. At the opposite pole, the countries with the lowest level of the surface incoming shortwave flux are UK and Austria.

Analyzing Figures 4 and 5, we observed that there is an anticorrelation between black carbon and shortwave flux, which is normal. However, none of the two is recommended for the preservation or conservation in good condition of the cultural heritage.

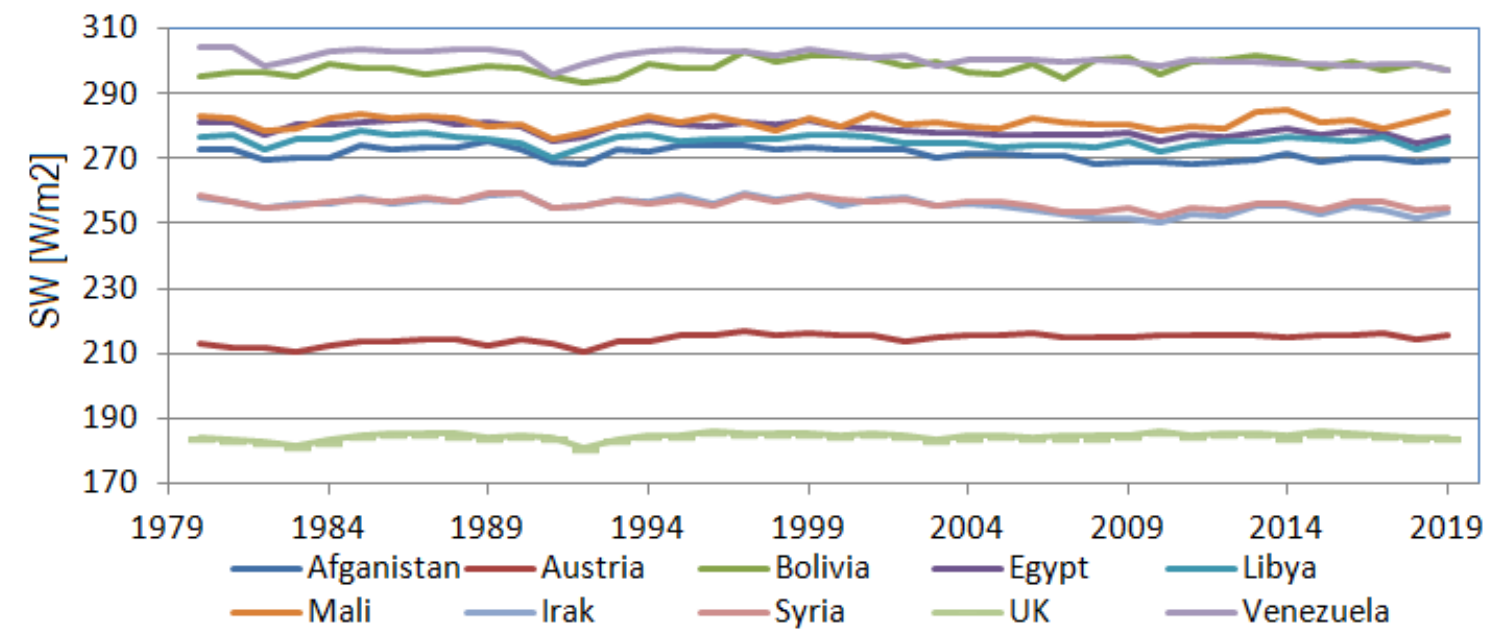

Fig. 4. The average surface incoming shortwave flux (clear sky) over the selected countries

\section{CONCLUSIONS}

In this work, we presented that the use of space-borne measurements and the associated products of models based on space observations can be used as a very useful tool on the evaluation of the radiation and atmospheric pollution over the cultural heritage sites. We showed the level of black carbon surface mass concentration and the average surface incoming shortwave flux over ten countries: Afghanistan, Austria, Bolivia, Egypt, Iraq, Libya, Mali, Syria, UK, Venezuela. 
We found that the countries with the highest level of mass black carbon are Austria and UK, while the countries with the highest shortwave flux radiation are Venezuela and Bolivia. Note that there is an interdependence (natural anti-correlation) between black carbon and shortwave flux radiation which make the countries with the highest black carbon to be the lowest on the top of shortwave flux radiation and vice versa. Also, we show a global map of $\mathrm{NO}_{2}$ using TROPOMI observations.

\section{Acknowledgement}

This work was supported by a grant of the Romanian Ministry of Research and Innovation, CCCDI - UEFISCDI, project number PN-III-P1-1.2-PCCDI-2017-0878, contract no. 55PCCDI/2018, within PNCDI III. Also, we acknowledge the free use of TEMIS and NASA Giovanni database.

\section{References}

1. List of World Heritage in Danger, https://whc.unesco.org/en/danger/

2. Rosu, A., Constantin, D. E., Arseni, M., \& Timofti, M. (2020, March). Atmospheric measurements in the context of protection and conservation of cultural heritage objects. In AIP Conference Proceedings (Vol. 2218, No. 1, p. 030015). AIP Publishing LLC.

3. van Geffen, J.H.G.M., Eskes, H.J., Boersma, K.F., Maasakkers, J.D. and Veefkind, J.P., TROPOMI ATBD of the total and tropospheric NO2 data products, Report S5P-KNMI-L2-0005RP, KNMI, De Bilt, The Netherlands; see TROPOMI ATBD list for the latest available version.

4. N. Herascu, M. Simileanu, R. Radvan, "Color changes in the artwork materials aged by UV radiation", Romanian Reports in Physics, 60(1), 95-103, (2008).

5. Patrón, D., Lyamani, H., Titos, G., Casquero-Vera, J. A., Cardell, C., Močnik, G., ... \& Olmo, F. J. (2017). Monumental heritage exposure to urban black carbon pollution. Atmospheric environment, $170,22-32$.

6. MERRA-2 tavgM_2d_aer_Nx: 2d,Monthly mean, Time-averaged, Single-Level, Assimilation, Aerosol Diagnostics V5.12.4,

https://disc.gsfc.nasa.gov/datacollection/M2TMNXAER_5.12.4.html 